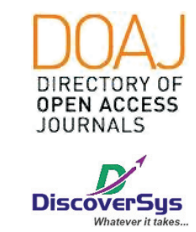

Published by DiscoverSys

\section{Durasi penggunaan lensa kontak dengan resiko terjadinya keratitis: tinjauan pustaka}

\author{
Agnes Angela Mahdalena Simanjuntak*
}

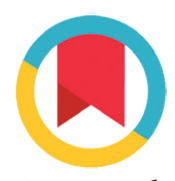

CrossMark

\title{
ABSTRACT
}

Introduction: An increase in the incidence of refractive disorders provides an increasing need for visual aids such as glasses and contact lenses. The use of long-term contact lenses provides a new problem which is adana keratitis which can arise with prolonged use of contact lenses.

Objective: The literature review this time aims to provide a review of how long the role of contact lens use is at risk for keratitis.
Conclusion: Extended use of contact lenses can increase the risk for corneal keratitis. The choice of contact lens type characteristics and duration of use is a matter that should be observed to avoid the risk of keratitis.

Keywords: lens, keratitis, infection, risk lens, keratitis, infection, risk.

Cite this Article: Simanjuntak, A.A.M. 2020. Durasi penggunaan lensa kontak dengan resiko terjadinya keratitis: tinjauan pustaka. Intisari Sains Medis 11(1): 66-74. D0I: 10.15562/ism.v11i1.561

\section{ABSTRAK}

Pendahuluan: Peningkatan kejadian kelainan refraksi memberikan semakin tingginya kebutuhan akan alat penunjang pengelihatan seperti kaca mata dan lensa kontak. Adanya penggunaan lensa kontak jangka panjang memberikan suatu masalah baru yang yaitu adana keratitis yang dapat muncul dengan lama penggunaan lensa kontak.
Tujuan: Tinjauan pustaka kali ini bertujuan untuk memberikan suatu ulasan mengenai bagaimana peranan penggunaan lensa kontak yang panjang terhadap risiko dari keratitis.

Simpulan: Penggunaan lensa kontak secara extended dapat meningkatkan risiko untuk terjadi keratitis kornea. Pemilihan karakteristik jenis lensa kontak dan durasi penggunaan menjadi hal yang patut dicermati untuk menghindari risko keratitis.

Kata kunci: lensa, keratitis, infeksi, risiko.

Cite Pasal Ini: Simanjuntak, A.A.M. 2020. Durasi penggunaan lensa kontak dengan resiko terjadinya keratitis: tinjauan pustaka. Intisari Sains Medis 11(1): 66-74. D0I: 10.15562/ism.v11i1.561

\section{PENDAHULUAN}

Tingkat kasus kelainan refraksi mata secara global semakin mengalami peningkatan. Lensa kontak merupakan salah satu alat bantu penglihatan yang sangat umum digunakan oleh masyarakat untuk koreksi kelainan refraksi, tujuan kosmetik, maupun sebagai pilihan terapi untuk kondisi patologi kornea., ${ }^{1,2}$ Penggunaan lensa kontak semakin dipilih pada era saat ini oleh karena banyak keunggulan yang ditawarkan, diantaranya yaitu lebih praktis dan harga yang terjangkau. ${ }^{1}$ Besar penjualan lensa kontak secara global di Inggris diperkirakan mencapai 12.476,3 juta dolar pada tahun 2020, dengan laju pertumbuhan mencapai $6,7 \% .^{3}$ Sensus yang dilaksanakan pada tahun 2006 mendapatkan bahwa sebanyak 125 juta orang di seluruh dunia menggunakan lensa kontak.,

Lensa kontak memberikan rasa nyaman dan koreksi penglihatan secara efektif apabila penggunaan dan perawatan lensa dilakukan secara adekuat sesuai dengan rekomendasi dokter., ${ }^{1,5}$ Lensa kontak diresepkan untuk manajemen pasien dengan gangguan refraksi yang tidak dapat diterapi dengan penggunaan kaca mata, seperti kasus aphakia, keratokonus, kornea ireguler, dan anisometropia yang tinggi. ${ }^{1,6}$ Selain itu, lensa kontak juga dapat digunakan untuk manajemen gangguan refraksi sederharna sebagai alternatif penggunaan kaca mata. ${ }^{3,6}$

Namun, pengguna lensa kontak sangat mungkin memiliki risiko infeksi pada mata apabila pengguna gagal menggunakan, membersihkan, mendisinfeksi dan menyimpan lensa kontak sesuai dengan yang direkomendasikan. ${ }^{6,7}$ Pada tahun 2016 telah dilaporkan bahwa lebih dari 41 juta pengguna lensa kontak di Amerika Serikat yang melaporkan pola 
perilaku penggunaan lensa kontak yang menempatkan mereka pada risiko mengalami infeksi mata. ${ }^{1}$ Beberapa gejala yang dilaporkan terjadi pada pengguna lensa kontak secara berkelanjutan di Amerika Serikat yaitu sensasi terbakar, gatal atau berair, dan lebih banyak dilaporkan oleh pengguna usia remaja. ${ }^{1}$ Sebuah penelitian di Riyadh, ditemukan bahwa sebesar 38,7\% pengguna lensa kontak tidak berkonsultasi terlebih dahulu sebelum mulai menggunakan lensa kontak. ${ }^{1,3}$

Komplikasi penggunaan lensa kontak secara umum merupakan kondisi yang self-limiting jika lensa kontak dilepaskan, namun pengecualian pada keratitis-terkait lensa kontak. ${ }^{2}$ Keratitis atau infeksi pada kornea merupakan salah satu komplikasi yang dapat ditimbulkan akibat penggunaan lensa kontak secara tidak tepat. ${ }^{8}$ Kondisi ini cukup jarang namun berpotensi membahayakan kondisi penglihatan. ${ }^{2}$ Namun, dengan semakin meningkatnya penggunaan lensa kontak oleh masyarakat, angka kejadian keratitis khususnya keratitis mikroba juga mengalami peningkatan. ${ }^{8}$ Pada pasien yang dilaporkan dengan kebutaan, opasitas kornea berkontribusi sebesar $4 \%$, atau menduduki peringkat keempat penyebab kebutaan di seluruh dunia, dengan faktor etiologi utama yaitu keratitis infeksi. ${ }^{9}$ Beberapa faktor risiko yang berkaitan dengan kejadian keratitis infeksi terkait penggunaan lensa kontak yaitu penggunaan lensa kontak setiap hari termasuk pada malam hari saat tidur, kebersihan tangan yang kurang, higienitas lensa dan penyimpanan yang buruk, dan usia remaja. ${ }^{8}$

Sebagai salah satu faktor risiko yang dapat dimodifikasi, pemahaman mengenai durasi penggunaan lensa kontak yang aman perlu ditinjau lebih mendalam. Maka dari itu, pada kesempatan ini penulis tertarik untuk meninjau beberapa kepustakaan terkait hubungan antara durasi penggunaan lensa kontak dengan risiko terjadinya keratitis, yang diharapkan mampu menambah wawasan dalam mengedukasi pengguna lensa kontak sebagai upaya untuk mencegah komplikasi terkait lensa kontak.

\section{ANATOMI DAN FISIOLOGI KORNEA}

Kornea merupakan jaringan yang transparan dan avaskuler. Kornea melindungi stuktur okuler dan berperan $70 \%$ dalam kekuatan refraksi mata. ${ }^{10}$ Rerata dimensi yang dimiliki oleh kornea yaitu :

- radius permukaan anterior sebesar 7,86 mm,

- diameter horizontal sebesar $11,8 \mathrm{~mm}$,

- ketebalan sentral 0,52 mm,

- ketebalan perifer yaitu $1,00 \mathrm{~mm} .{ }^{10}$

Kornea terdiri dari tiga lapisan dan dua membran. ${ }^{10,11}$ Lapisan superfisial atau anterior disebut sebagai lapisan epitel, lapisan bagian tengah disebut sebagai stroma, lapisan paling dalam atau posterior disebut endotel, dan dua membran pembatas yaitu membran Bowman,dan membran Descemet (Gambar 1). Masing-masing lapisan ini tersusun atas struktur dan tipe sel yang berbeda yang memberikan gambaran yang unik dan respon yang berbeda ketika mengalami suatu penyakit. ${ }^{11}$

Lapisan epitel tersusun atas epitel skuamosa berlapis dan tidak berkeratin dan juga disusun oleh sel kolumnar basal selapis yang dilekatkan oleh hemi-desmosom menuju membran basalis, diikuti dengan dua atau tiga baris sel epitel dan dua lapisan eksternal sel permukaan skuamosa yang area permukaannya diperluas dengan mikroplika dan mikrovilli yang memfasilitasi ikatan lapisan musin dari tear film. Setelah dua puluh empat jam, sel-sel superfisial akan menyebar ke tear film. Sel punca epitel berlokasi di area limbus (area antara kornea dan sklera), di dalam palisade Vogt utamanya di bagian superior dan inferior dari limbus. Sel punca kornea sangat penting untuk memelihara kesehatan epitel kornea dan berperan sebagai barrier yang mencegah pertumbuhan epitel konjungtiva menuju kornea. ${ }^{11}$

Lapisan stroma menyusun hampir $90 \%$ dari total ketebalan kornea, lapisan ini merupakan lapisan avaskuler tersusun atas $78 \%$ air, kolagen tipe I dan lapisan fibril $\mathrm{V}$ yang didukung oleh substansi proteoglikan (kondroitin dan keratan sulfat) dengan sel-sel fibroblas termodifikasi yang tersebar luas. ${ }^{10}$ Bagian superfisial dari stroma disebut sebagai membran Bowman yang menyusun bagian aseluler dari stroma. Pada bagian ini terdapat persebaran serat-serat kolagen dari lapisan stroma yang menyebabkan struktur kornea menjadi transparan, sehingga spektrum cahaya memungkinkan untuk masuk menuju struktur mata yang lebih dalam. ${ }^{11}$

Lapisan endotel tersusun atas sel heksagonal selapis yang berada di atas membran basalis, yang disusun oleh anyaman serat kolagen yang disebut

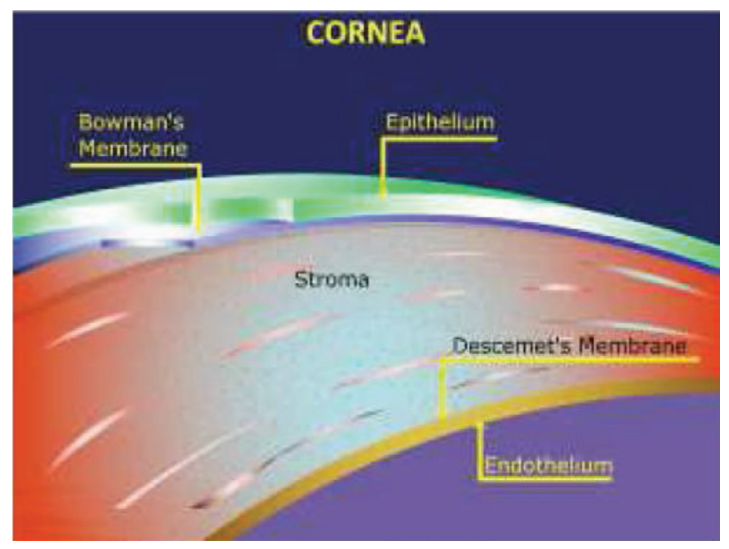

Gambar 1 Anatomi kornea 
membran Descemet. Lapisan ini berperan penting dalam menjaga transparansi kornea dengan mengurangi jumlah air di dalam stroma kornea melalui mekanisme kanal membran aktif yang memungkinkan pergerakan air dari stroma menuju bilik mata depan. Sel endotel tidak dapat beregenerasi karena sel tersebut dorman pada fase G1 siklus sel. ${ }^{10,11}$

Pada tahun 2013, lapisan Dua diperkenalkan untuk pertama kalinya. Lapisan Dua merupakan suatu lapisan kolagen tipis (15 mikron) yang terletak diantara stroma kornea dan membran Descemet. Lapisan ini memiliki resistensi terhadap tekanan yang paling tinggi diantara lapisan penyusun kornea. ${ }^{11}$

Makrofag dan antigen presenting cell dendritik ditemukan terutama pada epitel dan stroma anterior. Selain itu, sejumlah kecil makrofag juga ditemukan di stroma posterior. Inervasi sensorik kornea berasal dari nervus trigeminalis $\left(\mathrm{V}_{1}\right)$ dan terdistribusi pada area sub-epitel dan stroma anterior sebagai pleksus sub-epitel. ${ }^{10,11}$

\section{Keratitis}

Keratitis merupakan suatu proses peradangan pada kornea. Keratitis terkait penggunaan lensa kontak atau ulser perifer terkait lensa kontak ditandai dengan adanya ekskavasi, infiltrat dan membran Bowman yang intak. ${ }^{11}$

Beberapa faktor risiko berkaitan dengan keratitis telah diteliti dimana dua faktor risiko utama tingginya angka kejadian keratitis adalah penggunaan lensa kontak semalaman dan higienitas yang buruk, dengan proporsi masing-masing yaitu $43 \%$ dan 33\% dari total seluruh faktor risiko keratitis terkait penggunaan lensa kontak. ${ }^{3,12}$

\section{Patogenesis Keratitis}

Penyakit kornea merupakan permasalahan yang signifikan dan sering tidak dilaporkan. World Health Organization (WHO) mengestimasi bahwa $1 \%$ dari gangguan penglihatan global diakibatkan oleh infeksi kornea atau inflamasi. Keratitis infeksi dialami oleh sekitar 4000 pasien di Inggris setiap tahunnya, dimana angka kejadiannya semakin meningkat seiring dengan peningkatan penggunaan lensa kontak. Gangguan penglihatan pada keratitis infeksi merupakan hasil dari (i) interaksi antara pathogen dengan jaringan host, (ii) respon inflamasi innate host, dan (iii) terapi yang dilakukan untuk mengobati infeksi. ${ }^{9,13}$

Epitel kornea yang intak menjadi barrier untuk penetrasi bakteri menuju lapisan kornea yang lebih dalam. Hal ini didukung ileh ikatan kuat dan sangat rapat antara sel-sel superfisial dan juga adanya peptida antibakteri serta pensinyalan imun innate. Selain itu, cairan air mata mengandung musin, imunoglobulin sekretori A (sIg A) dan surfaktan protein D, yang merupakan faktor-faktor antimikroba yang dapat mengikat mikroba. Penetrasi bakteri ke dalam stroma membutuhkan celah trauma pada epitel kornea, baik secara mekanik seperti abrasi, atau inokulasi intrasomal pada keratitis mikroba. ${ }^{9,13}$

Sel imun seperti makrofag dan sel dendritik memiliki peran penting untuk memulai respon imun innate pada kornea dengan mengekspresikan pattern-recognition receptors (PRR) seperti Toll-like receptor (TLR) dan NOD-like receptor. Ketika PRR ini diaktifkan, akan memicu kaskade pelepasan sitokin proinflamasi seperti interleukin (IL)-1, IL-6, dan IL-8 via NF-kB untuk melawan pathogen., ${ }^{9,13}$

\section{Lensa Kontak}

Lensa kontak secara efektif menutup kornea dari lingkungan oksigen normal, air mata dan sekresi okuler. Efek yang ditimbulkan bergantung pada ketebalan lensa kontak, ukuran, metode penggunaan, dan material yang digunakan. Pada konteks ini, digunakan beberapa definisi: ${ }^{10}$

- Anoksia terjadi ketika tidak ada oksigen.

- Hipoksia terjadi ketika terjadi penurunan suplai oksigen terhadap jaringan okuler.

- Hiperkapnea merupakan akumulasi dari karbondioksida. ${ }^{10}$

Jenis lensa kontak bergantung pada berbagai parameter dari perspektif ilmiah material. Saat ini kebanyakan lensa kontak diproduksi melalui proses polimerisasi dari dua atau lebih monomer. Polimerisasi radikal bebas merupakan jenis polimerisasi chain-growth. Polimerisasi ini secara tipikal mampu memproduksi polimer dengan berat molekul yang sangat bervariasi. Istilah kopolimer digunakan untuk menyatakan penggabungan properti-properti dari polimer-polimer tunggal, dimana metode ini digunakan untuk mengatasi permasalahan pada polimer tunggal (Gambar 2). Misalnya pada polimer silikon, selain memiliki properti hidrofobik, polimer ini juga memiliki properti permeabilitas oksigen yang tinggi. Sedangkan istilah komonomer digunakan untuk menyatakan penggabungan properti-properti monomer pada suatu properti. Misalnya pada properti hidrofobik yang ditambahkan dengan monomer permeabilitas oksigen untuk meningkatkan kualitasnya (Tabel 1). ${ }^{5}$

Permeabilitas oksigen sebuah material dinyatakan dalam satuan $\mathrm{Dk}$, menyatakan sebuah properti fisik dari material lensa kontak dan menjelaskan kemampuan intrinsiknya dalam mentransportasikan oksigen. Permeabilitas oksigen dapat didefinisikan sebagai laju aliran oksigen 
dibawah kondisi tertentu per unit ketebalan area material lensa kontak pada unit tekanan yang berbeda. Permeabilitas oksigen bukanlah bentuk atau ketebalan fungsional dari material namun selalu berubah sesuai dengan suhu. Semakin tinggi suhu, maka Dk akan semakin tinggi. ${ }^{10}$

Sedangkan kemampuan transmisi oksigen dinyatakan dalam satuan $D k / t$, dengan $t$ mewakili ketebalan lensa atau material sampel. $D k / t$ untuk lensa tertentu pada kondisi tertentu didefinisikan sebagai kemampuan lensa untuk mengalirkan oksigen dari permukaan anterior menuju posterior. ${ }^{10}$

Kandungan air merupakan jumlah cairan yang diambil oleh material lensa sebagai persentase keseluruhan dalam kondisi tertentu. Kandungan air atau dinyatakan dalam satuan persen (\%) dihitung dengan cara mengurangi kandungan air pada lensa yang terhidrasi penuh dengan kandungan air pada lensa yang terdehidrasi penuh, dibagi dengan kandungan air pada lensa yang terhidrasi penuh, dan dikali $100 \%$. Air akan hilang akibat evaporasi khususnya terjadi pada penggunaan lensa hidrogel. ${ }^{5,10}$

Kelebihan yang dimiliki lensa dengan kandungan air yang rendah yaitu tidak mudah rusak, lebih tahan lama, dan dehidrasi yang rendah pada mata. Sedangkan kelemahannya yaitu kecenderungan untuk menyebabkan edema kornea yang lebih besar, kecenderungan untuk menyebabkan vaskularisasi seiring dengan tebalnya lensa. Sedangkan untuk lensa dengan kandungan air yang lebih tinggi memiliki keunggulan diantaranya lebih nyaman karena material akan lebih lembut, adaptasi yang lebih cepat, durasi pemakaian yang lebih lama, dapat digunakan secara "extended", dan baik digunakan secara intermiten. Disamping kelebihan yang ditawarkan, beberapa kelemahannya yaitu tidak tahan lama, lebih rapuh, deposit titik-titik putih yang lebih banyak, memerlukan waktu yang lebih lama untuk menggunakannya, lensa lebih terdehidrasi. ${ }^{10}$

\section{Jenis Lensa Kontak}

Lensa kontak telah mengalami perkembangan dalam segi material atau bahan penyusunnya. ${ }^{5,10}$ Perkembangan dimulai dari lensa sklera kaca pada tahun 1930an, kemudian berkembang menjadi lensa rigid, non-gas-permeable polymethyl methacrylate (PMMA) pada tahun 1940an. Pada kisaran tahun 1960 hingga 1970an, penggunaan lensa hidrogel (polimer dan silikon) dengan hidrogel silikon menjadi bahan yang paling banyak digunakan hingga saat ini. ${ }^{5}$

Lensa kontak "hard" bersifat rigid dan merupakan lensa gas-permeable. Sedangkan lensa kontak "soft" terbuat dari material yang kaya akan kandungan air dan bersifat fleksibel. Istilah lensa keras sering digunakan untuk menggantikan istilah lensa rigid gas-permeable (RGP). Namun, penggunaan istilah ini tidak selalu tepat. Lensa PMMA pertama dapat digolongkan sebagai lensa "hard", sedangkan lensa RGP modern memiliki struktur yang lebih fleksibel. ${ }^{5,10}$ Beberapa kelebihan dan kelemahan material lensa kontak ditampilkan pada Tabel 2.

Lensa kontak PMMA tersebar di pasaran sebanyak $1 \% .^{5}$ Jenis lensa kontak ini telah digunakan sejak tahun 1940an, pertama kali sebagai pengganti lensa sklera kaca, dan merupakan suatu bahan pilihan seiring dengan berkembangnya lensa kornea. ${ }^{10}$ PMMA merupakan polimer transparan yang tahan lama dan dengan karakter hidrofilik yang terbatas (Gambar 3). PMMA memiliki permeabilitas oksigen yang kurang bahkan tanpa kandungan oksigen, dan dapat menyebabkan beberapa kesehatan mata seperti hipoksia. ${ }^{5,10}$ Ketika lensa kontak tidak memiliki permeabilitas oksigen, maka metabolisme kornea akan secara keseluruhan bergantung pada pertukaran air mata. ${ }^{14,15}$ Pada saat ini, penggunan lensa kontak PMMA masih dikesampingkan baik untuk penelitian maupun tujuan komersial. ${ }^{5}$

Lensa kontak RGP modern saat ini telah tidak menggunakan material PMMA, atau secara signifikan mengurangi fraksi molar PMMA pada banyak kopolimer. Penggunaan lensa RGP di Inggris mencapai 14\% pada tahun 2017. Pada sebuah penelitian dilaporkan bahwa lensa RGP dengan diameter besar digunakan sebagai terapi pada pasien pasca operasi laser in situ keratomileusis (LASIK). Keuntungan yang ditawarkan oleh lensa RGP adalah strukturnya yang rigid, sehingga mampu untuk membentuk kembali kornea, yang bermanfaat sebagai terapi pada pasien pasca operasi. ${ }^{5}$ RGP biasanya memberikan hasil visual yang lebih baik dibandingkan material hidrogel pada mata yang memiliki astigmatisme dengan permukaan kornea reguler atau ireguler. ${ }^{14}$

Hidrogel HEMA merupakan jenis lensa kontak dengan persentase pemakaian mencapai $22 \%$. Lensa kontak hidrogel HEMA memiliki kandungan air yang tinggi, dan tersusun atas material polimer oksigen permeabel. Lensa kontak hidrogel memiliki kandungan air yang berkisar antara 20\%-80\% tergantung pada komonomer yang digunakan. Pada lensa kontak hidrogel yang hanya disusun oleh HEMA, kandungan air yang dimiliki sebesar $38 \%$. Lensa kontak dengan bahan hidrogel ini memiliki permeabilitas oksigen yang tinggi sehingga menyebabkan lensa jenis ini dapat digunakan dalam waktu lama namun tidak selama pemakaian lensa yang berbahan dasar silikon. HEMA pada umumnya mengalami kopolimerisasi dengan monomer-monomer seperti EGDMA, MAA, dan NVP. Monomer NVP dan MAA meningkatkan kandungan air pada hidrogel oleh karena karakter 
<smiles>COC(=O)C(CC(C)(C)C)C(C)(C)C</smiles><smiles>CCCC(C)C(C)O</smiles><smiles>OCCO[PH3]</smiles><smiles>C=CC(=O)N(C)C</smiles><smiles>C=C(C)C(=O)OCCO</smiles>

HEMA<smiles>C=CN1CCCC1=O</smiles>
NVP<smiles>C=C(C)C(=O)OCCOC(=O)C(=C)C</smiles>

EGDMA<smiles>C[Si](C)(C)O[Si](C)(C)O[Si](C)(C)C</smiles>

PDMS<smiles>C=C(C)C(=O)OCCC[Si](O[Si](C)(C)C)(O[Si](C)(C)C)O[Si](C)(C)C</smiles>

Gambar 2 Struktur kimia monomer dan polimer yang digunakan untuk memproduksi lensa kontak. Gambar ini meliputi beberapa makromonomer dan agen cross-linking. PMMA- poly methyl methacrylate, PVA-poly vinyl alcohol, PEG- poly ethylene glycol, DMAdimethyl methacrylate, HEMA- hydroxy ethyl methacrylate, NVP$N$-vinyl pyrrolidone, EGDMA- ethylene glycol dimethacrylate, PDMS-poly dimethyl siloxane, TRIS-3-[tris(trimethylsiloxy)silyl] propyl methacrylate ${ }^{5}$

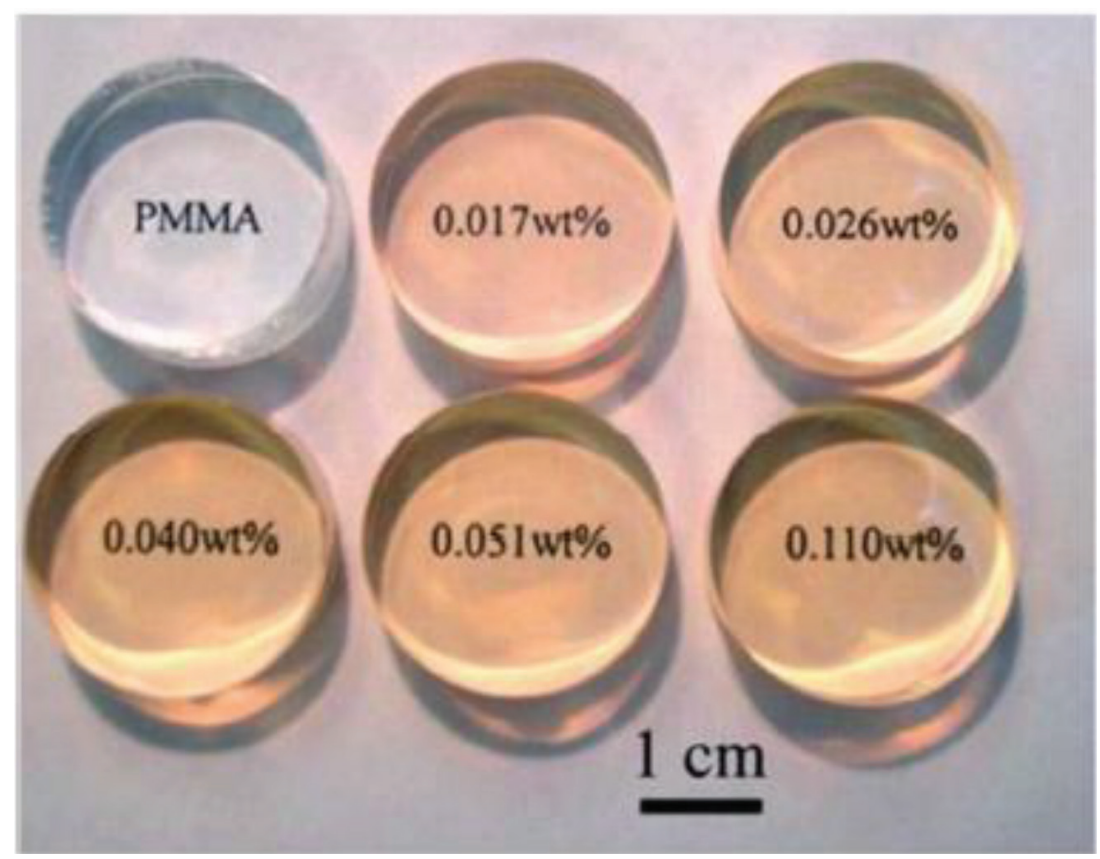

Gambar 3 PMMA button dengan titik kuantum $\mathrm{ZnO}$ yang akan diproses untuk membentuk lensa kontak final ${ }^{5}$

hidrofiliknya yang kuat. Properti mekanik dapat ditingkatkan dengan menggunakan molekul cross-linking seperti EGDMA. ${ }^{5}$ Lensa speris hidrogel diindikasikan untuk mengoreksi miopia dan hipermetropia jika astigmatisme kurang dari 1.00 dioptri (D) dan air mata masih cukup. ${ }^{14}$
Hidrogel silikon merupakan bahan lensa kontak yang paling banyak digunakan pada masa kini, yaitu mencapai $64 \%$. Tipe lensa kontak ini meliputi silikon, silioxane, fluorosiloxane, dan material turunan lainnya. Popularitas lensa kontak ini berkaitan dengan fakta bahwa jenis lensa kontak ini memiliki permeabilitas oksigen yang paling tinggi dibandingkan jenis material lainnya $(>100$ Dk). Lensa kontak silikon memiliki sifat yang tahan lama, yang berasal dari energi ikatan Si-O. Faktanya, sensasi tidak nyaman dan kering yang ditimbulkan oleh lensa berbahan dasar silikon merupakan dua alasan utama pemberhentian penggunaan lensa ini. $^{5}$

Material lensa kontak lainnya yaitu polyvinyl alcohol hydrogel (PVA), merupakan suatu polimer sintetik yang mengandung banyak rantai hidroksi $(-\mathrm{OH})$. Rantai tersebut merupakan sumber dari properti hidrofilik dan biokompatibilitas lensa ini. Lensa biokompatibel didefinisikan sebagai kemampuan material untuk menghadapi substansi alami tanpa memicu reaksi biologis. Hal ini memberikan keuntungan bahwa respon fisiologisnya baik dengan penurunan evaporasi air mata serta penurunan deposit kornea. ${ }^{10}$ Hidrogel PVA merupakan kelas lensa hidrogel yang relatif baru dibandingkan dengan hidrogel silikon dan HEMA. Lensa ini memiliki Dk sebesar 26 dan wettability yang tinggi yang menyebabkan lensa ini dapat diterima untuk penggunaan sehari-hari., ${ }^{5,14}$

\section{Keratitis Terkait Penggunaan Lensa Kontak}

Keratitis mikroba merupakan suatu inflamasi aktif pada kornea yang disebabkan oleh mikroorganisme seperti bakteri, virus, atau parasit terkait dengan penggunaan lensa kontak yang merupakan faktor risiko yang paling penting (Tabel 3). ${ }^{4}$ Keratitis dapat terjadi akibat hipoksia, mikrotrauma, dan kontaminasi lensa kontak atau kontaminasi cairan lensa kontak. ${ }^{3,4}$ Risiko keratitis semakin meningkat hingga 20 kali lipat pada penggunaan extended yang meningkatkan hipoksia kornea. Trauma mekanik pada epitel kornea ditandai dengan erosi epitel pungtuata, yang berhubungan dengan penggunaan lensa kontak hidrogel-silikon. Adanya kerusakan barrier epitel dapat menjadi faktor risiko serius untuk mengalami keratitis infeksi.

Insiden keratitis bakteri per tahun diperkirakan mencapai 2 per 10.000 pengguna lensa kontak, tergantung pada jenis lensa kontak yang digunakan dan program pemakaian, dengan rentangan antara $1,2 \%$ untuk penggunaan lensa kontak RGP diurnal dan 25,4\% untuk penggunaan lensa kontak hidrogel silikon extended (Gambar 4)., ${ }^{3,12}$

Infeksi protozoa pada mata secara prinsip disebabkan oleh penggunaan lensa kontak yang terkontaminasi atau cairan lensa yang 
Tabel 1 Properti beberapa material lensa kontak

\begin{tabular}{lcccc}
\hline Material & $\begin{array}{c}\text { Permeabilitas } \\
\text { oksigen (Dk/t) }\end{array}$ & $\begin{array}{c}\text { Kandungan air } \\
\text { (wt\%) }\end{array}$ & $\begin{array}{c}\text { Modulus } \\
\text { (MPa) }\end{array}$ & $\begin{array}{c}\text { Waktu Penggunaan } \\
\text { (hari)** }\end{array}$ \\
\hline PMMA & 0 & 0 & 1000 & $<1$ \\
PMMA-silikon & 15 & 0 & 10 & $1-7$ \\
Silikon-HEMA (rigid) & $10-100$ & 0 & $0,2-2$ & \\
Hidrogel HEMA & $10-50$ & $30-80$ & & $7-28$ \\
HEMA-NVP & & & $0,2-2$ & \\
HEMA-MMA & & & & $<1$ \\
Hidrogel silikon (PDMS) & $60-200$ & $20-55$ & & \\
TRIS-DMA & & & & \\
PDMS-HEMA & & $60-70$ & & \\
PVA & $10-30$ & & & \\
\hline
\end{tabular}

${ }^{*}$ Waktu penggunaan maksimum tanpa komplikasi ekstensif pada mata sebelum pelepasan lensa kontak

Tabel 2 Kelebihan dan kelemahan material lensa kontak yang umum digunakan

\begin{tabular}{lll}
\hline Material Lensa Kontak & Kelebihan & Kelemahan \\
\hline PMMA & Murah & $\begin{array}{l}\text { Tidak memiliki permeabilitas oksigen, } \\
\text { tidak fleksibel pada mata }\end{array}$ \\
RGP & Permeabilitas oksigen tinggi, tahan lama & $\begin{array}{l}\text { Mahal, membutuhkan ko-monomer } \\
\text { hidrofilik, dapat bersifat abrasif }\end{array}$ \\
Hidrogel HEMA & $\begin{array}{l}\text { Murah, biokompatibel, kemungkinan } \\
\text { kopolimer yang banyak }\end{array}$ & $\begin{array}{l}\text { Permeabilitas oksigen rendah, masalah } \\
\text { deposisi protein }\end{array}$ \\
Hidrogel silikon & $\begin{array}{l}\text { Permeabilitas oksigen tinggi, tahan lama, } \\
\text { nyaman }\end{array}$ & $\begin{array}{l}\text { Mahal, membutuhkan ko-monomer } \\
\text { hidrofilik, dapat bersifat abrasif }\end{array}$ \\
PVA & Murah, biokompatibel & $\begin{array}{l}\text { Permeabilitas oksigen rendah, kandungan } \\
\text { air tidak bisa diubah }\end{array}$ \\
\hline
\end{tabular}

Tabel 3 Permasalahan keratitis terkait penggunaan lensa kontak

\begin{tabular}{llll}
\hline Etiologi & Definisi & Insiden & Faktor Risiko \\
\hline Bakteri & $\begin{array}{l}\text { Inflamasi aktif pada kornea } \\
\text { akibat mikroorganisme } \\
\text { seperti bakteri, fungi, } \\
\text { parasit sebagai hasil dari } \\
\text { penggunaan lensa kontak }\end{array}$ & $1,2 \%-25,4 \%$ & Hipoksia \\
& & $1-33$ per 1 juta & Mikrotrauma \\
Achantamoeba & & Kontaminasi \\
Fungi & & $\begin{array}{l}\text { Penggunaan } \text { extended } \\
\text { terkait penggunaan lensa } \\
\text { kontak }\end{array}$ & Komplians yang buruk \\
& & & Lensa hidrogel \\
& & & Trauma \\
& & & Penyakit sistemik
\end{tabular}

terkontaminasi. Amoeba yang hidup bebas dari genus Achantamoeba merupakan agen kausal pada infeksi yang mengancam penglihatan. Insiden keratitis Achantamoeba di negara berkembang mencapai 1-33 kasus per 1 juta pengguna lensa kontak (Gambar 5).,3,4,12

Keratitis fungi dilaporkan terjadi pada $21 \%$ pasien pengguna lensa kontak. Keratitis ini ditandai dengan infiltrat berwarna putih keabuan dengan infiltrasi yang dalam. Lesi satelit sebagai tanda spesifik mungkin dapat ditemukan, sedangkan hipopion cukup jarang ditemukan. Diagnosis dikonfirmasi melalui pemeriksaan mikrobiologi. Faktor risiko utama terjadinya keratitis fungi adalah penggunaan lensa kontak. Risiko tertinggi ditemukan pada penggunaan lensa kontak hidrogel silikon, sedangkan penggunaan lensa RGP memiliki risiko paling rendah (Gambar 6), 3,12 


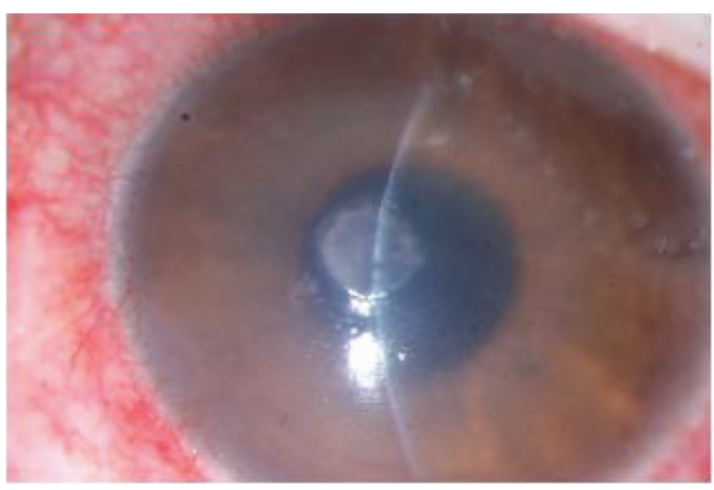

Gambar 4 Keratitis bakteri pada pasien pengguna lensa minisklera ${ }^{3}$

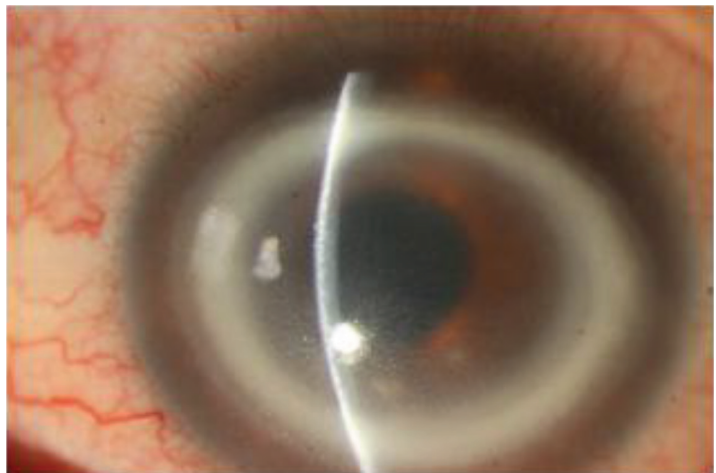

Gambar 5 Keratitis Achantamoeba ${ }^{3}$

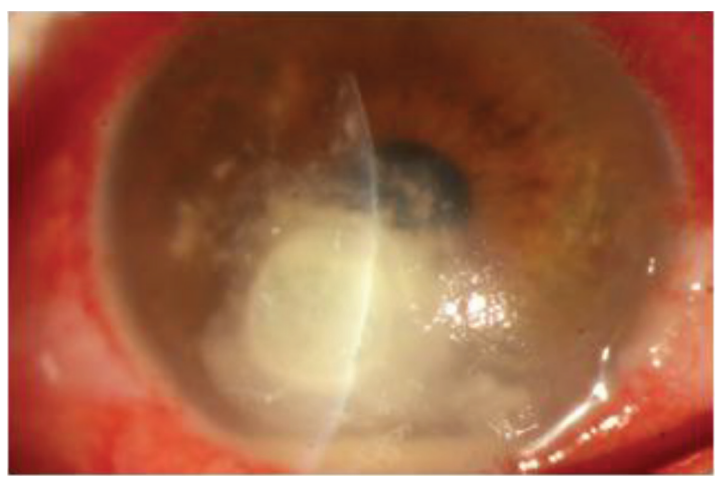

Gambar 6 Keratitis Fungi ${ }^{3}$

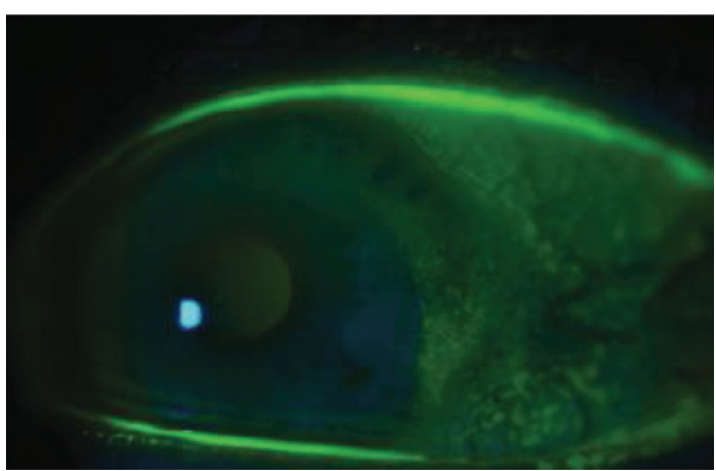

Gambar 7 Staining pada posisi jam 3 akibat kering pada pasien dengan lensa PMMA $^{16}$

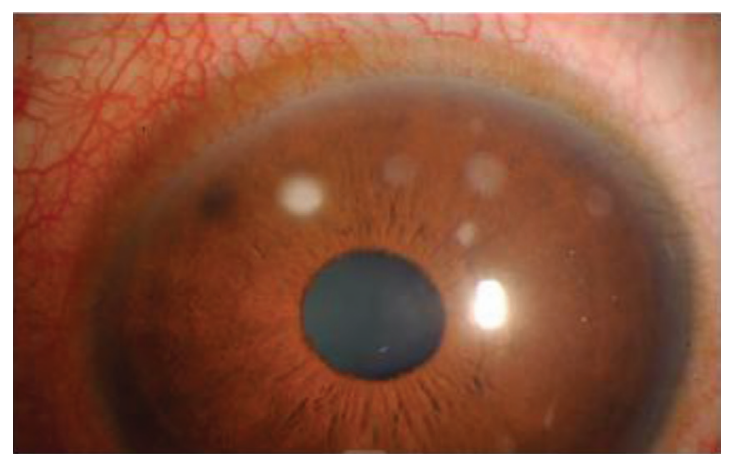

Gambar 8 Scar kornea multipel berhubungan dengan ulkus perifer lensa kontak ${ }^{17}$

\section{Hubungan Durasi Penggunaan Lensa Kontak Dengan Keratitis}

Penggunaan lensa kontak semalaman telah dilakukan untuk beberapa tahun. Baik prevalensi dan keparahan komplikasi khususnya keratitis mikroba semakin meningkat ketika lensa kontak digunakan secara extended yaitu melebihi satu atau lebih siklus tidur. FDA membatasi penggunaan lensa hidrogel extended maksimal untuk 6 malam, sedangkan beberapa hidrogel silikon dan lensa kontak dengan $D k$ yang tinggi disetujui penggunaannya hingga 1 bulan berturut-turut. Namun beberapa penelitian telah mendapatkan hasil bahwa meskipun menggunakan lensa kontak dengan permeabilitas oksigen yang sangat tinggi, jika digunakan secara extended, akan memicu risiko terjadinya infeksi pada kornea. ${ }^{14}$

Insiden keratitis mikroba terkait penggunaan lensa kontak masih stabil dengan laju 2-4 per 10.000 pengguna lensa kontak per tahun untuk pengguna lensa kontak setiap hari (tanpa penggunaan saat tidur), sedangkan angka kejadian mengalami peningkatan di kalangan pengguna lensa kontak semalaman dengan laju 20 per 10.000 pengguna lensa kontak. Meskipun diperkenalkannya material lensa hidrogel-silikon yang mampu menghilangkan tekanan hipoksia pada kornea selama penggunaan semalaman, tidak ada penurunan risiko keratitis bakteri pada pengguna lensa kontak. ${ }^{12}$

Pada pengguna lensa kontak dengan keluhan nyeri berat pada mata perlu dipikirkan kemungkinan terjadinya keratitis dengan etiologi Acanthamoeba. Sindrom mata merah terkait lensa kontak menyerang mereka yang menggunakan lensa kontak "extended" dengan sindrom 3.a.m (yang disebabkan karena kering dan kedipan mata yang kurang) dan secara tipikal terjadi pada penggunaan lensa kontak PMMA dan lensa dengan $D k$ yang rendah (Gambar 7). Kondisi nyeri berat tersebut akan menyebabkan pasien terbangun pada malam hari. Sensasi tidak nyaman dapat terjadi pada periode adaptif terutama pada penggunaan 
lensa rigid. Lensa RGP yang terlalu kecil atau terlalu besar dapat mengiritasi kelopak mata. Lensa "soft" yang tidak mencapai limbus juga akan menimbulkan sensasi tidak nyaman ketika berkedip karena lensa akan bergerak menuju limbus. ${ }^{16}$

Ulkus perifer lensa kontak, pada tahap aktif akan tampak sebagai ekskavasi fokal epitel, infiltrasi dan nekrosis dari stroma anterior. Ulkus berukuran kecil (mencapai $2 \mathrm{~mm}$ ), tunggal, dan terdapat infiltrat fokal sirkuler. Tampak area limbus dan bulbi yang kemerahan, dengan nyeri berat hingga moderate, disertai dengan sensasi adanya benda asing pada mata. ${ }^{17}$ Pada sebuah review mengenai faktor risiko terjadinya infiltrat pada pengguna lensa kontak mendapatkan bahwa penggunaan lensa semalaman telah berhubungan dengan peningkatan risiko terbentuknya infiltrat. Sebanyak hampir $25 \%$ dari seluruh pasien melaporkan penggunaan lensa kontak "extended" dan minimal semalaman secara "occasional". Laju insiden keratitis berat setiap tahunnya mencapai masing-masing 6,4 dan 96,4 per 10.000 untuk pengguna lensa kotak rutin dan "extended", yang menunjukkan bahwa terjadi peningkatan risiko sebesar 8,1 kali lipat untuk mengalami keratitis pada pasien yang menggunakan lensa kontak "extended". Penggunaan lensa kontak berkelanjutan lebih dari 3 minggu memiliki risiko yang lebih kecil untuk terbentuknya infiltrat pada kelompok pasien yang tidur menggunakan lensa kontak selama lebih dari 30 hari (Gambar 8). Hal ini mungkin menunjukkan keberhasilan penggunaan lensa kontak yang menyebabkan kelompok pengguna lensa kontak dalam durasi yang lebih panjang, merasa nyaman dan melanjutkan penggunaan hingga 30 hari. $^{17}$

Pada penelitian Ibrahim dkk pada tahun 2018, didapatkan bahwa penggunaan lensa kontak semalaman dilaporkan berhubungan dengan peningkatan risiko keratitis mikroba. Hal ini didukung oleh penelitian yang dilakukan di Riyadh, Maldives dan Australia. ${ }^{1}$ Penggunaan lensa kontak semalaman meningkatkan risiko terjadinya keratitis mikroba sebesar 2,9 kali lipat. ${ }^{18}$

Penelitian oleh Stapleton dkk dengan subjek 963 pengguna lensa kontak sekali pakai juga melaporkan bahwa penggunaan lensa kontak sekali pakai selama semalaman dan hampir setiap hari dalam satu minggu merupakan faktor risiko independen yang mempengaruhi kejadian keratitis mikrobial. Menggunakan lensa kontak sesering mungkin berhubungan dengan risiko keratitis sebesar 93\% untuk seluruh kasus, dan sebesar $72 \%$ berhubungan dengan kasus yang lebih berat. ${ }^{8}$

Penelitian yang dilakukan di Singapura, mendapatkan bahwa penggunaan lensa kontak sejak pagi hingga malam hari namun kurang dari satu malam per minggu memiliki peningkatan risiko sebesar empat kali lipat untuk mengalami keratitis mikrobial dibandingkan dengan penggunaan lensa kontak reguler semalaman. Namun hasil ini dapat dipengaruhi oleh rendahnya penggunaan lensa kontak jangka panjang di Singapura. ${ }^{2}$

Pada sebuah survei yang dilakukan di Inggris, ditemukan bahwa sebanyak 50,2\% pengguna lensa kontak pernah menggunakan lensa kontak semalaman hingga saat tidur. Tidur menggunakan lensa kontak seringkali menjadi suatu kebiasaan yang dilaporkan. Meskipun banyak lensa kontak "soft" dan beberapa lensa kontak rigid mendapat memenuhi indikasi dan telah disetujui sebagai lensa kontak yang dapat digunakan semalaman, tidup dengan menggunakan lensa kontak jenis apapun dapat meningkatkan risiko terjadinya infeksi mata, meskipun mekanisme jelasnya belum diketahui. Penggunaan lensa kontak sekali pakai atau daily disposable contact lens mungkin memiliki risiko infeksi mata yang lebih rendah karena mengganti lensa kontak setiap hari sesuai dengan rekomendasi. ${ }^{19}$

\section{SIMPULAN}

Penggunaan lensa kontak secara extended dapat meningkatkan risiko untuk terjadi keratitis kornea. Kemudian dasar pemilihan bahan lensa kontak, jenis lensa disposable atau pun non-disposable, serta sifat permeabilitas lensa terhadap oksigen menjadi factor-faktor yang perlu dipertimbangkan dalam menggunakan lensa kontak.

\section{KONFLIK KEPENTINGAN}

Penulis menyatakan tidak terdapat suatu konflik kepentingan terkait publikasi dari artikel ini.

\section{DAFTAR PUSTAKA}

1. Ibrahim NK, Seraj H, Khan R, Baabdullah M, Reda L. Prevalence, habits and outcomes of using contact lenses among medical students. Pak J Med Sci. 2018; 34(6):1429-34.

2. Lim CHL, Carnt NA, Farook M, Lam J, Tan DT, Mehta JS, dkk. Risk factors for contact lens-related microbial keratitis in Singapore. Eye (Lond). 2016; 30(3): 447-55.

3. Alipour F, Khaheshi S, Soleimanzadeh M, Heidarzadeh S, Heydarzadeh S. Contact lens-related complications: A review. J Ophthalmic Vis Res. 2017; 12(2): 193-204.

4. Prasannakumary C dan Jyothy PT. Complications of contact lens. Kerala J Ophthalmolo. 2017; 29: 68-71.

5. Musgrave CSA dan Fang F. Contact lens materials: a materials science perspective. Materials. 2019; 12:261-97.

6. Edward K, Keay L, Naduvilath T, Stapleton F. The penetrance and characteristics of contact lens wear in Australia. Clin Exp Optom. 2014; 97:48-54.

7. Stapleton F, dan Carnt N. Contact lens-related microbial keratitis: how have epidemiology and genetics helped us with pathogenesis and prophylaxis. Eye. 2012; 26: 185-93.

8. Stapleton F, Naduvilath T, Keay L, Radford C, Dart J, Edwards K, dkk. Risk factors and causative organisms in microbial keratitis in daily disposable contact lens wear. Plos ONE. 2017; 12(8):e0181343. 
9. Taube MA, Cendra MDM, Elsahn A, Christodoulides M, Hossain P. Pattern recognition receptors in microbial keratitis. Eye. 2015; 29: 1399-1415.

10. Gason A dan Morris JA. The contact lens manual-A practical. 3rd ed. London. 2003. 1-92.

11. Pacheco AP. Keratitis-A clinical approach. IntechOpen. 2014;10: 206-23.

12. Carnt N, Samarawickrama C, Stapleton F. The diagnosis and management of contact lens-related microbial keratitis. Clin Exp Optom. 2017; 100:482-93.

13. Fleisig SMJ dan Evans DJ. The pathogenesis of contact lens-associated microbial keratitis. Optom Vis Sci. 2010; 87(4): 225-32.

14. Weissman BA, Barr, JT, Harris MG, Kame RT, McMahon TT, Rah M, dkk. Optometric clinical practice guideline care of contact lens patient. 2nd ed. Lindbergh Blvd., St. Louis. 2006. 11-8.

15. Muntz A, Subbaraman LN, Sorbara L, Jones L. Tear exchange and contact lenses: a review. J Optom. 2014; 12:1-10.

16. Millis EAW. Medical contact lens practice. 1st ed. London. 2005. 46-75.
17. Steele KR, dan Flynn LS. Epidemiology of contact lens-induced infiltrates: an update review. Clin Exp Optom. 2017; 100: 473-81.

18. Booranapong W, Prabhaswat P, Kosrirukvongs P, Tarawarcharasart Y. Risk factors for contact lens related microbial keratitis: A case-control study. J Med Assoc Thai. 2012; 95(5):693-8.

19. Cope KR, Collier SA, Rao MM, Chalmers R, Mitchell L, Richdale K. Contact lens wearer demographics and risk behaviors for contact lens-related eye infections-United States, 2014. Morb Mortal Wkly Rep. 2015; 64 (32): 867-88.

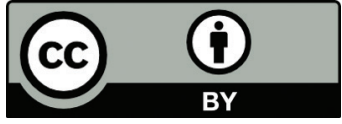

This work is licensed under a Creative Commons Attribution 